\title{
Analisis Pengelolaan Retribusi Daerah Sebagai Strategi Peningkatan Pendapatan Asli Daerah (PAD) (Studi Kasus pada Seluruh Organisasi Perangkat Daerah (OPD) Terkait Retribusi di Kabupaten Tulungagung)
}

\author{
Andy Kurniawan ${ }^{a} *$ \\ ${ }^{a}$ Universitas Brawijaya, Malang, Jawa Timur, Indonesia
}

\section{INFORMASI ARTIKEL}

\section{Article history:}

Dikirim tanggal: 4 Januari 2019

Revisi pertama tanggal: 26 Februari 2019

Diterima tanggal: 23 April 2019

Tersedia online tanggal: 30 April 2019

Keywords: local retributions, local ownsource reveneu, growth analysis, contribution, performance, overlay analysis

\begin{abstract}
Good management of regional levies based on the provisions of the Regional Tax and Retribution Act No. 28 of 2009 is a strategy to optimize income to support regional development. This is important for regional prosperity and becomes a benchmark for regional independence. In-depth analysis of the conditions and developments of the realization of revenue from regional levies can illustrate the problems that occur. The four technical analyzes used were growth analysis, contribution, performance and overlay analysis, which eventually resulted in a description of the object of retribution that had a high leakage rate. Thus a strategy can be formulated that can provide concrete recommendations in order to optimize the receipt of regional retribution as one of the spearheads in increasing PAD in Tulungagung District.
\end{abstract}

\section{INTISARI}

Pengelolaan retribusi daerah yang baik yang berpedoman pada ketentuan Undangundang Pajak dan Retribusi Daerah Nomor 28 Tahun 2009 menjadi strategi optimalisasi pendapatan guna mendukung pembangunan daerah. Hal ini penting untuk kemakmuran daerah dan menjadi tolak ukur kemandirian daerah. Analisis mendalam mengenai kondisi dan perkembangan dari realisasi penerimaan retribusi daerah dapat menggambarkan permasalahan yang terjadi. Empat teknis analisis yang digunakan yaitu analisis pertumbuhan, kontribusi, kinerja dan analisis overlay yang pada akhirnya dihasilkan deskripsi objek retribusi yang memiliki tingkat kebocoran tinggi. Dengan demikian dapat dirumuskan strategi yang dapat memberi rekomendasi konkret guna mengoptimalkan penerimaan retribusi daerah sebagai salah satu ujung tombak dalam meningkatkan PAD di Kabupaten Tulungagung.

\section{Pendahuluan}

Retribusi daerah merupakan sumber pendapatan daerah yang penting dalam menjalankan pemerintahan daerah. Peningkatan pendapatan daerah dapat berbanding lurus dengan meningkatnya pelayanan kepada masyarakat serta menjadi tolak ukur kemandirian daerah.
Akan tetapi dalam upaya peningkatan retribusi daerah yang ditetapkan berdasar peraturan daerah harus berpedoman pada ketentuan yang diatur dalam UndangUndang pajak dan retribusi daerah.

Kabupaten Tulungagung merupakan salah satu daerah otonom diwilayah Provinsi Jawa Timur yang terus menggali potensi keuangan agar dapat meningkatkan

\footnotetext{
* Corresponding author. Tel.: +62-822-2924-7848; e-mail: andy_fia@ub.ac.id
} 
PAD salah satunya melalui retribusi daerah. Retribusi daerah di Kabupaten Tulungagung memiliki potensi pendapatan yang tinggi. Hal ini memungkinkan untuk memberikan kontribusi yang lebih besar terhadap PAD.

Selama beberapa tahun terakhir (Tahun 2013-2017) bahwa pertumbuhan pendapatan dari retribusi daerah mencapai $8,42 \%$. Meskipun terjadi pertumbuhan, data menunjukkan bahwa pada Tahun 2017 retribusi daerah di Kabupaten Tulungagung memiliki capaian realisasi sebesar 99,94\% atau Rp. 23.258.789.789 dari target yang ditetapkan dalam APBD sebesar Rp. 23.273.886.598. Hal ini menunjukkan bahwa pengelolaan retribusi daerah masih belum berjalan dengan baik.

Selain itu, Kabupaten Tulungagung masih memiliki masalah mendasar dalam pengelolaan retribusi daerah. Pertama, adanya petugas parkir insidental di GOR Lembu Peteng yang menarik tarif retribusi parkir melebihi ketentuan perda (Basso, 2017). Kedua, perda retribusi izin tempat penjualan minuman beralkohol masih belum berjalan dengan baik sehingga berdampak pada meningkatnya tempat hiburan yang menyediakan minuman beralkohol tanpa izin (Pramono, 2017).

Melihat permasalahan diatas, maka perlu dilakukan analisis yang lebih dalam terkait dengan kondisi dan perkembangan dari realisasi penerimaan retribusi daerah yang dihasilkan, sehingga dapat diketahui berbagai permasalahan yang dihadapi oleh OPD terkait misalnya pos objek retribusi yang memiliki tingkat kebocoran retribusi yang relatif tinggi yang perlu dilakukan pengawasan ekstra. Dengan demikian dapat merumuskan strategi atau langkah-langkah/ upaya yang dapat dilakukan untuk optimalisasi penerimaan retribusi daerah. Hasil analisis dapat menjadi dasar dalam merumuskan berbagai kebijakan yang dapat mendukung peningkatan dan perbaikan pengelolaan retribusi daerah Kabupaten Tulungagung sebagai salah satu sumber PAD.

\section{Teori}

\section{$2.1 \quad P A D$}

Pendapatan Asli Daerah adalah penerimaan yang diperoleh daerah dari sumber-sumber dalam wilayahnya sendiri yang dipungut berdasarkan peraturan daerah sesuai dengan peraturan perundang-undangan yang berlaku (Siahaan, 2005). Ahmad Yani (2002) menyebutkan bahwa PAD merupakan penerimaan yang bersumber dalam wilayah daerah sendiri berdasar pada peraturan daerah yang berlaku. Sumber PAD yaitu dari pajak daerah, retribusi daerah, hasil pengelolaan kekayaan daerah yang dipisahkan dan lain-lain PAD yang sah.

\subsection{Retribusi Daerah}

Retribusi daerah yang selanjutnya disebut retribusi adalah pungutan daerah sebagai pembayaran atas jasa atau pemberian izin tertentu yang khusus disediakan dan/ atau diberikan oleh pemerintah daerah untuk kepentingan orang pribadi atau badan. Pungutan daerah atas pembayaran jasa atau pemberian suatu izin yang disediakan dan/ atau diberikan oleh pemerintah daerah untuk kepentingan orang pribadi atau badan. Terdapat tiga jenis yaitu, retribusi jasa umum, usaha, dan perizinan tertentu (Agus, 2011).

\subsection{Tingkat Pertumbuhan}

Untuk mengetahui tingkat pertumbuhan masingmasing jenis retribusi daerah digunakan rumus:

$$
\begin{aligned}
& \Delta \mathrm{X}_{\mathrm{i}}=\frac{X i t-X i t(t-1)}{X i t(t-1)} \times 100 \% \\
& \text { Keterangan: } \\
& \Delta \mathrm{X}_{\mathrm{i}} \quad \text { : Rasio pertumbuhan jenis retribusi } \\
& \mathrm{X}_{\text {it }} \text { :Jumlah jenis retribusi tahun ke } \mathrm{t} \\
& \mathrm{X} \text { it (t-1): Jumlah jenis retribusi tahun ke } \mathrm{t}-1
\end{aligned}
$$

\subsection{Analisis Tingkat Kontribusi}

Untuk mengetahui kontribusi masing-masing jenis retribusi daerah digunakan rumus:

$$
\begin{aligned}
& \Delta \mathrm{Xi}=\frac{X i}{X} \times 100 \% \\
& \text { Keterangan: } \\
& \Delta \mathrm{Xi}_{\mathrm{i}} \text { : Rasio kontribusi jenis retribusi daerah } \\
& \mathrm{Xi} \quad \text { Total retribusi daerah }
\end{aligned}
$$

\subsection{Klasifikasi Jenis Retribusi Daerah (Overlay)}

Analisis Overlay digunakan untuk melihat deskripsi kegiatan jenis retribusi daerah potensial berdasarkan kriteria pertumbuhan dan kriteria kontribusi. Untuk mengetahui jenis retribusi daerah diperlukan identifikasi atau klasifikasi kondisi yang didasarkan pada jumlah serta perkembangan setiap jenis PAD. Identifikasi ini dilakukan dengan cara mematrik antara komposisi penerimaan dan pertumbuhan penerimaan sebagai berikut:

Tabel 1 Matrik Komposisi Penerimaan dan Pertumbuhan

\begin{tabular}{|l|l|l|}
\hline Pertumbuhan & $\begin{array}{c}\text { KXi } \geq 1 \\
\text { (tinggi) }\end{array}$ & $\begin{array}{c}\text { wXi }<1 \\
(\text { rendah })\end{array}$ \\
\hline $\mathrm{gXi} \geq 1$ (tinggi) & Prima & Berkembang \\
\hline $\mathrm{gXi}<1$ (rendah) & Potensial & Terbelakang \\
\hline
\end{tabular}

Sumber: Jaya, 1996

Berdasarkan analisis overlay dan klasifikasi retribusi daerah secara garis besar dikelompokan menjadi empat kondisi, yaitu sebagai berikut:

a) Prima: Retribusi daerah memberikan kontribusi dan pertumbuhan sama dengan atau lebih dari $1 \%$; 
b) Prima: Retribusi daerah memberikan kontribusi dan pertumbuhan sama dengan atau lebih dari $1 \%$;

c) Potensial: Retribusi daerah memberikan kontribusi sama dengan atau lebih dari $1 \%$ sedangkan pertumbuhan kurang dari $1 \%$;

d) Berkembang: Retribusi daerah memberikan kontribusi kurang dari $1 \%$ sedangkan pertumbuhan sama dengan atau lebih dari $1 \%$;

e) Terbelakang: Retribusi daerah memberikan kontribusi dan pertumbuhan kurang dari $1 \%$.

\subsection{Kinerja Retribusi Daerah}

Analisis kinerja retribusi daerah dilakukan dengan menggunakan perhitungan dan analisis tingkat ekonomis, tingkat efisiensi dan tingkat efektivitas.

\subsubsection{Tingkat Ekonomis}

Menunjukkan perbandingan antara realisasi biaya dengan anggaran biaya yang ditetapkan.

$$
=\frac{\begin{array}{c}
\text { Tingkat } \\
\text { Realisasi Pengeluaran }
\end{array}}{\text { Anggaran Pengeluaran }} \times 100 \%
$$

\section{Ekonomis}

Kriteria yang digunakan dalam menilai tingkat ekonomis retribusi daerah adalah:

Tabel 2 Kriteria Tingkat Ekonomis

\begin{tabular}{|c|l|l|}
\hline No & \multicolumn{1}{|c|}{$\begin{array}{c}\text { Persentase Kinerja } \\
\text { Keuangan }\end{array}$} & \multicolumn{1}{c|}{ Kriteria } \\
\hline 1 & Kurang dari $100 \%$ & Ekonomis \\
\hline 2 & Sama dengan $100 \%$ & Berimbang \\
\hline 3 & Lebih dari $100 \%$ & Tidak Ekonomis \\
\hline
\end{tabular}

Sumber: Mahsun, 2013

\subsubsection{Efisiensi}

Menunjukkan nilai yang dihitung berdasarkan persentase biaya pemungutan retribusi daerah dengan realisasi penerimaan retribusi daerah.

Tingkat Efisiensi $=$
$\frac{\text { Biaya Pemungutan Retribusi }}{\text { Realisasi Penerimaan Retribusi }} \times 100 \%$

Tabel 3 Kriteria Tingkat Efisiensi

\begin{tabular}{|c|l|l|}
\hline No & \multicolumn{1}{|c|}{ \% Kinerja Keuangan } & \multicolumn{1}{|c|}{ Kriteria } \\
\hline 1 & Kurang dari $100 \%$ & Efisien \\
\hline 2 & $100 \%$ & Berimbang \\
\hline 3 & Lebih dari $100 \%$ & Tidak Efisien \\
\hline
\end{tabular}

Sumber: Mahsun, 2013

\subsubsection{Efektivitas}

Merupakan perbandingan antara realisasi dan target penerimaan retribusi daerah, sehingga dapat digunakan sebagai ukuran keberhasilan dalam melakukan pungutan.

Tabel 4 Kriteria Tingkat Efektivitas

\begin{tabular}{|c|l|l|}
\hline No & \multicolumn{1}{|c|}{$\%$ Kinerja Keuangan } & \multicolumn{1}{c|}{ Kriteria } \\
\hline 1 & $>100 \%$ & Sangat Efektif \\
\hline 2 & $100 \%$ & Efektif \\
\hline
\end{tabular}

\begin{tabular}{|c|l|l|}
\hline No & \multicolumn{1}{|c|}{$\%$ Kinerja Keuangan } & \multicolumn{1}{|c|}{ Kriteria } \\
\hline 3 & $90-99 \%$ & Cukup Efektif \\
\hline 4 & $75-89 \%$ & Kurang Efektif \\
\hline 5 & $<75 \%$ & Tidak Efektif \\
\hline
\end{tabular}

Sumber: Mahmudi, 2010

$$
\begin{gathered}
\text { Tingkat } \\
\frac{\text { Eealisasi Penerimaan Retribusi }}{\text { Target Penerimaan Retribusi }}
\end{gathered}
$$

Pada kegiatan ini tingkat efektivitas juga ditinjau berdasarkan perbandingan antara realisasi retribusi daerah terhadap PAD, dengan perhitungan sebagai berikut:

$$
\begin{gathered}
\text { Tingkat Efektivitas }= \\
\frac{\text { Realisasi Penerimaan Retribusi }}{\text { Realisasi Penerimaan PAD }} \times 100 \%
\end{gathered}
$$

Kriteria yang digunakan dalam menilai efektivitas retribusi daerah ini adalah sebagai berikut:

Tabel 5 Kriteria Efektivitas Terhadap PAD

\begin{tabular}{|c|l|l|}
\hline No & \multicolumn{1}{|c|}{ Persentase Kinerja } & \multicolumn{1}{|c|}{ Kriteria } \\
\hline 1 & $1,72 \%$ keatas & Sangat Efektif \\
\hline 2 & $1,30-1,72 \%$ & Efektif \\
\hline 3 & $0,87-1,29 \%$ & Cukup Efektif \\
\hline 4 & $0,43-0,86 \%$ & Kurang Efektif \\
\hline 5 & Dibawah $0,43 \%$ & Tidak Efektif \\
\hline
\end{tabular}

Sumber: Mahsun, 2013

\section{Metode Penelitian}

Pendekatan penelitian, yaitu kuantitatif deskriptif. Instrumen penelitian digunakan dalam pengumpulan data, analisis data bersifat kuantitatif/ statistik. Metode yang dipakai bertujuan untuk mendeskripsikan objek penelitian atupun hasil penelitian. Objek pada penelitian ini adalah Badan Pendapatan Daerah Kabupaten Tulungagung dan menggunakan data primer maupun sekunder, data primer berasal dari informasi langsung yang diberikan staf atau pimpinan OPD. Sedangkan data sekunder berasal dari buku, makalah, hasil penelitian, peraturan dan dokumentasi.

\section{Hasil Penelitian dan Pembahasan}

Pemerintah daerah harus memaksimalkan segala potensi daerahnya dengan meningkatkan kapasitas atau kemampuan yang optimal dalam memungut retribusi daerah guna optimalisasi penerimaan retribusi daerah. Retribusi Jasa umum dalam undang-undang terdapat 14 jenis, hanya saja Pemerintah Kabupaten Tulungagung menetapkan lima jenis retribusi jasa umum. Penerapan ini merupakan pilihan bagi pemerintah karena merasa potensi dari lima objek ini tinggi, sedangkan sembilan objek lain dinilai kurang potensial. Kemudian untuk retribusi jasa usaha menerapkan delapan objek retribusi dari 11 objek yang diatur dalam undang-undang. Untuk retribusi perizinan tertentu menerapkan tiga objek dari 
lima objek yang tercantum dalam undang-undang. Pemaparan setiap jenis retribusi sebagai berikut:

\section{$4.1 \quad$ Analisis Pengelolaan Retribusi}

\subsubsection{Pelayanan Kesehatan}

Retribusi ini dikelola Dinas Kesehatan dengan realisasi sebesar Rp. 4.788.357.000 pada Tahun 2016 dan tumbuh sebesar $13,02 \%$ pada Tahun 2017, sehingga jumlah realisasi pada tahun tersebut mencapai Rp. 5.412.025.000. Peningkatan disebabkan oleh meningkatnya jumlah pasien yang menggunakan program BPJS di Puskesmas. Hal tersebut terlihat dari peningkatan retribusi dari Rp. 2.925.013.000 menjadi Rp. 3.625.990.000 pada Tahun 2017. Dengan adanya peningkatan jumlah realisasi menyebabkan terjadinya peningkatan kontribusi, dimana tingkat kontribusi terhadap total penerimaan retribusi daerah pada Tahun 2016 mencapai $21,11 \%$ dan meningkat menjadi $23,26 \%$.

Pada Tahun 2016 dan 2017 target tidak tercapai, dimana target penerimaan Rp. 5.562.907.626 terealisasi Rp. 4.788.357.000 pada Tahun 2016. Tingkat efektivitas Tahun 2016 sebesar 86,08\% dengan kriteria kurang efektif. Demikian pula pada Tahun 2017, dimana target penerimaan Rp. 6.302.805.126, dan terealisasi Rp. 5.412.025.000. Artinya tingkat efektivitas 85,67\% atau dengan kriteria kurang efektif.

Tingkat efektivitas terhadap PAD Tahun 2016 dan 2017 menunjukkan hasil yang baik, dimana tingkat efektivitas pada Tahun 2016 sebesar 1,40\%, artinya dalam pemungutan sudah sangat efektif. Demikian pula pada Tahun 2017 tingkat efektivitas terhadap PAD mencapai $1,08 \%$, walaupun terjadi penurunan namun masih termasuk dalam kategori sangat efektif. Tingkat ekonomis retribusi ini adalah $81,2 \%$ masuk dalam kriteria ekonomis artinya penyerapan anggaran yang digunakan untuk menunjang pengelolaan retribusi pelayanan kesehatan tahun 2017 mencapai 81,2\%. Nilai tingkat efisiensi pada Tahun 2017 menunjukan kriteria efisien dengan nilai $32,81 \%$, dimana dari jumlah biaya yang dikeluarkan Rp. 1.775.786.000, telah mampu menghasilkan jumlah pendapatan retribusi yang lebih besar, yaitu Rp. 5.412.025.000.

\subsubsection{Retribusi Pelayanan Persampahan}

Realisasi Retribusi ini mencapai Rp. 538.332.900, dimana mengalami pertumbuhan negatif atau penurunan $-4,21 \%$, sehingga jumlah realisasi Rp. 515.665 .750 pada Tahun 2017. Tingkat kontribusi terhadap total penerimaan retribusi daerah Tahun 2017 mengalami penurunan menjadi $2,21 \%$ dari kontribusi tahun sebelumnya yang mencapai $2,37 \%$. Target penerimaan tercapai di Tahun 2016 dan 2017, dimana target Tahun 2016 sebesar Rp. 508.880.000 telah berhasil terealisasi Rp. 538.332.900, sehingga tingkat efektivitasnya $105,79 \%$ dengan kriteria sangat efektif. Demikian pula pada Tahun 2017, dimana target penerimaan retribusi pelayanan persampahan Rp. 477.525.000 dengan jumlah realisasi penerimaan mencapai Rp. 515.665.750 dengan tingkat efektivitas $107,99 \%$ atau masuk dalam kriteria sangat efektif.

Tingkat efektivitas Retribusi Pelayanan Persampahan terhadap PAD Tahun 2016 sebesar 0,16\%, artinya dalam pemungutannya dinilai kurang efektif. Pada Tahun 2017 mengalami penurunan menjadi $0,10 \%$, sehingga termasuk dalam kategori tidak efektif. Terjadinya penurunan lebih banyak dipengaruhi oleh adanya penurunan jumlah realisasi.

Tingkat ekonomis Retribusi Pelayanan Persampahan pada Tahun 2017 sebesar 100\% dengan kriteria ekonomis berimbang, dimana jumlah realisasi biaya yang dibutuhkan dalam pengelolaan Retribusi Pelayanan Persampahan telah sesuai dengan yang dianggarkan. Selain tingkat ekonomis, tingkat efisiensi pada dasarnya menunjukkan nilai yang dihitung berdasarkan persentase biaya pemungutan dengan realisasi penerimaan. Nilai tingkat efisiensi menunjukan kriteria efisien sebesar $0,77 \%$, dimana dengan jumlah pendapatan retribusi pada Tahun 2017 yang mencapai Rp. 515.665.750, maka jumlah realisasi biaya/ belanja yang digunakan dalam pemungutan Retribusi Pelayanan Persampahan tersebut sebesar Rp. 4.000.000.

\subsubsection{Retribusi Parkir Tepi Jalan Umum}

Pada Tahun 2016 realisasi Rp. 7.225.504.500 dan tumbuh 2,97\% pada Tahun 2017 menjadi Rp. 7.439.954.500. Pertumbuhan disebabkan oleh tumbuhnya jumlah kendaraan bermotor, baik roda dua dan roda empat. Seiring pertumbuhan ini, maka tingkat kontribusi realisasi Retribusi Parkir di Tepi Jalan Umum terhadap total penerimaan retribusi daerah pada Tahun 2016 telah mencapai $31,86 \%$, dan meningkat menjadi 31,98\% pada Tahun 2017.

Pada Tahun 2016 dan 2017, target penerimaan tercapai, dimana pada Tahun 2016 dengan target penerimaan Rp. 6.903 .125 .500 telah terealisasi Rp. 7.225.504.500. Tingkat efektivitas pada Tahun 2016 sebesar 104,67\% dengan kriteria sangat efektif. Demikian pula pada Tahun 2017, dimana target penerimaan Retribusi Parkir ditepi jalan umum meningkat menjadi Rp. 7.047.815.900 dengan realisasi penerimaan Rp. 7.439.954.500. dengan tingkat efektivitas $105,56 \%$ dalam kriteria sangat efektif.

Bila melihat pada tingkat efektivitas yang didasarkan pada proporsi realisasi Retribusi Parkir ditepi jalan umum terhadap PAD dapat diketahui bahwa, pada Tahun 2016 memiliki tingkat efektivitas 2,11\%, artinya pemungutannya sangat efektif. Demikian pula pada Tahun 2017, tergolong masih sangat efektif, walaupun tingkat efektivitasnya mengalami penurunan hingga menjadi $1,48 \%$. 
Tingkat ekonomis Tahun 2017 sebesar 100\% dengan kriteria ekonomis berimbang. Tingkat ekonomis menunjukkan perbandingan antara realisasi biaya dengan anggaran biaya yang ditetapkan, sehingga dengan demikian angka $100 \%$ menunjukkan bahwa anggaran yang dialokasikan untuk membiayai pengelolaan/ pemungutan tahun 2017. Nilai tingkat efisiensi pada Tahun 2017 menunjukan kriteria efisien dengan nilai $1,8 \%$, dimana dengan jumlah realisasi retribusi yang mencapai Rp. 7.439.954.500,00, besarnya biaya yang digunakan dalam mengelola Rp. 134.562.500.

\subsubsection{Retribusi Pelayanan Pasar}

Realisasi Tahun 2016 sebesar Rp. 3.242.132.490, tumbuh 3,02\% ditahun 2017 menjadi Rp. 3.340.104.040. Terjadinya peningkatan salah satunya disebabkan meningkatnya jumlah pedagang pasar, mengingat saat ini aktivitas perdagangan dengan berbagai jenis barang yang diperdagangkan semakin meningkat. Peningkatan ini menyebabkan terjadinya peningkatan kontribusi terhadap keseluruhan penerimaan retribusi, dimana tingkat kontribusi realisasinya terhadap total penerimaan retribusi daerah Tahun 2016 sebesar 14,29\%, dan meningkat menjadi $14,36 \%$.

Target penerimaan Tahun 2016 tercapai, yaitu Rp.3.150.000.000 dan realisasi penerimaannya sebesar Rp.3.242.132.490. Dengan demikian tingkat efektivitasnya adalah $102,92 \%$ dengan kriteria sangat efektif. Pada Tahun 2017, dimana target penerimaan sebesar Rp. 3.250.000.000 dengan realisasi penerimaan Rp. 3.340.104.040. Sehingga tingkat efektivitas sebesar $102,77 \%$ atau masuk dalam kriteria sangat efektif.

Tingkat efektivitas yang diukur berdasarkan kontribusi realisasi terhadap PAD Tahun 2016 menunjukkan angka sebesar $0,95 \%$, yang artinya pemungutan masuk dalam kategori sangat efektif. Demikian Tahun 2017, kontribusinya terhadap PAD masuk dalam kategori sangat efektif, walaupun nilai tingkat efektivitas menurun menjadi $0,66 \%$.

Tingkat ekonomis Tahun 2017 sebesar 91,99\% dengan kriteria ekonomis, dimana dari keseluruhan jumlah biaya/ belanja yang dianggarkan, sebesar 91,99\% telah terealisasi atau dapat dikatakan bahwa realisasi masih berada dibawah dari jumlah yang dianggarkan. Selain itu, tingkat efisiensi menggambarkan nilai yang dihitung berdasarkan persentase biaya pemungutan dengan realisasi penerimaan. Sedangkan tingkat efisiensi pada Tahun 2017 menunjukkan kriteria efisien dengan nilai $10,3 \%$, dimana keseluruhan biaya yang digunakan dalam mengelola/ memungut retribusi tersebut hanya sebesar $10,3 \%$ dari keseluruhan pendapatan retribusi yang diperoleh Tahun 2017 atau sebesar Rp. 347.112.000.

\subsubsection{Retribusi Pengujian Kendaraan Bermotor}

Realisasi retribusi ini sebesar Rp. 1.813.930.000 pada Tahun 2016 dan mengalami pertumbuhan negatif/ penurunan sebesar $-0,65$ menjadi Rp. 1.802.210.500. Penurunan disebabkan oleh menurunnya jumlah kendaraan bermotor yang melakukan ujian KIR, sehingga dengan demikian turut mempengaruhi realisasi retribusi. Penurunan realisasi berdampak terhadap penurunan kontribusi terhadap total penerimaan retribusi, dimana pada Tahun 2016 sebesar 8\%, dan menurun menjadi 7,74\% pada Tahun 2017.

Target penerimaan Retribusi Pengujian Kendaraan Bermotor pada Tahun 2016 telah tercapai dengan target penerimaan Rp. 1.573.689.725,00 dan realisasi penerimaannya Rp. 1.813 .930 .000 atau tingkat efektivitas sebesar $115,27 \%$ dengan kriteria sangat efektif. Demikian pula pada Tahun 2017, dimana jumlah target sebesar Rp. 1.593.885.002 dengan realisasi penerimaan Rp. 1.802.210.500, atau dapat dikatakan masuk dalam kriteria sangat efektif.

Tingkat efektivitas realisasi terhadap PAD Tahun 2016 sebesar 0,53\% yang artinya bahwa pemungutan Retribusi Pengujian Kendaraan Bermotor sangat efektif. Pada Tahun 2017 seiring dengan terjadinya penurunan realisasi menyebabkan tingkat efektivitas yang dihitung berdasarkan proporsi antara realisasi terhadap PAD mengalami penurunan menjadi $0,36 \%$. Hasil ini masuk dalam kategori efektif.

Nilai tingkat ekonomis yang dihasilkan dalam pengelolaan retribusi pengujian kendaraan bermotor sebesar $100 \%$ dengan kriteria ekonomis berimbang. Hal ini menggambarkan bahwa secara keseluruhan jumlah anggaran yang digunakan dalam pengelolaan dan pemungutan Tahun 2017 telah berhasil direalisasikan. Tingkat efisiensi Tahun 2017 menunjukan kriteria efisien dengan nilai 95,4\%. Hal tersebut menggambarkan bahwa jumlah realisasi biaya/ belanja yang dikeluarkan dalam pengelolaan/ pemungutan Retribusi Pengujian Kendaraan Bermotor masih berada di bawah keseluruhan jumlah pendapatan yang berhasil diterima pada Tahun 2017.

\subsubsection{Retribusi Pemakaian Kekayaan Daerah}

Realisasi Retribusi ini sebesar Rp. 3.061.644.682 pada Tahun 2016 dan mengalami pertumbuhan negatif atau penurunan sebesar $-1,70 \%$ pada Tahun 2017, sehingga jumlah realisasi Rp. 3.009.640.432. Terjadinya penurunan jumlah realisasi salah satunya disebabkan oleh menurunnya jumlah pemakaian beberapa kekayaan daerah, seperti pemakaian rumah dinas yang pada Tahun 2016 bisa mencapai Rp. 42.954.000, pada Tahun 2017 mengalami penurunan menjadi Rp. 39.410.000, selain itu untuk pemakaian lahan dan tanah pada Tahun 2017 juga 
mengalami penurunan. Seiring dengan penurunan jumlah realisasi, maka tingkat kontribusi realisasi terhadap total penerimaan juga mengalami penurunan, dimana tingkat kontribusi Tahun 2016 sebesar 13,5\%, dan turun menjadi $12,94 \%$ tahun berikutnya.

Pada Tahun 2016 telah berhasil memenuhi target penerimaan yang ditetapkan, dengan target Rp. 2.855.060.855 dan realisasi penerimaannya Rp. 3.061.644.682. Dengan tingkat efektivitas sebesar $107,22 \%$ atau masuk kriteria sangat efektif. Sedangkan pada Tahun 2017 dengan target penerimaan Rp. 3.025.696.620 realisasinya Rp. 3.009.640.432, artinya pada Tahun 2017 belum berhasil mencapai target dengan tingkat efektivitas 99,47\% (cukup efektif).

Tingkat efektivitas yang diperoleh dari proporsi antara realisasi retribusi ini terhadap PAD Tahun 2016 sebesar $0,89 \%$, artinya tergolong sangat efektif. Demikian pula Tahun 2017, masih termasuk dalam kategori sangat efektif, walaupun nilai tingkat efektivitasnya mengalami penurunan menjadi 0,6\%.

Retribusi Pemakaian Kekayaan Daerah Tahun 2017 memiliki tingkat ekonomis 98,77\% dengan kriteria ekonomis, dimana realisasi biaya yang digunakan untuk melakukan pengelolaan/ pemungutannya mampu mencapai 98,77\% dari anggaran biaya yang ditetapkan.

Kemudian untuk tingkat efisiensi Tahun 2017 menunjukan kriteria efisien dengan nilai $34 \%$, artinya dari jumlah realisasi pendapatan retribusi yang mencapai Rp. 3.009.640.432, jumlah biaya yang digunakan untuk melakukan pengelolaan sebesar Rp. 1.023.540.525.

\subsubsection{Retribusi Pasar Grosir/ Pertokoan}

Realisasi Tahun 2016 Rp. 198.455.800, dan mengalami pertumbuhan sebesar $2,67 \%$, menjadi Rp. 203.760.600. Peningkatan disebabkan meningkatnya jumlah pedagang pasar grosir/ pertokoan. Hal ini menyebabkan meningkatnya tingkat kontribusi terhadap total penerimaan retribusi daerah sebesar $0,87 \%$.

Pada Tahun 2016 dan 2017 target penerimaannya tercapai, dimana Tahun 2016 dengan target penerimaan Rp. $\quad 174.000 .000$ telah berhasil terealisasi Rp198.455.800. Dengan demikian tingkat efektivitas tahun 2016 sebesar 114,06\% (sangat efektif). Demikian pula pada Tahun 2017, dimana target Rp. 174.000.000 telah berhasil terealisasi Rp. 203.760 .600 dengan tingkat efektivitas $117,10 \%$ (sangat efektif).

Tingkat efektivitas yang diperoleh berdasarkan perhitungan dengan membandingkan antara realisasi retribusi pasar grosir/ pertokoan terhadap PAD pada Tahun 2016 sebesar 0,06\% atau termasuk dalam kategori tidak efektif. Demikian pula yang terjadi pada Tahun 2017, dimana tingkat efektivitas (perbandingan realisasi retribusi pasar grosir/ pertokoan terhadap PAD) mengalami penurunan menjadi $0,04 \%$, dan termasuk kategori tidak efektif. Kondisi tersebut menggambarkan bahwa kontribusi yang diberikan oleh retribusi pasar grosir/ pertokoan terhadap PAD masih rendah.

Tingkat ekonomisnya 0\% dengan kriteria ekonomis, dimana pada Tahun 2017 tidak terdapat anggaran yang dikhususkan untuk melakukan pengelolaan/ pemungutan. Sedangkan nilai tingkat efisiensi retribusi pasar grosir/ pertokoan menunjukan kriteria efisien dengan nilai $\infty \%$ (tidak terhingga), dimana dengan jumlah pendapatan yang diperoleh pada Tahun 2017 sebesar Rp. 203.760.600. Dinas Perindustrian dan Perdagangan tidak mengeluarkan biaya.

\subsubsection{Retribusi Tempat Pelelangan}

Realisasi Retribusi Tempat Pelelangan sebesar Rp. 9.466.000 dan mengalami pertumbuhan yang signifikan sebesar 660,63\% pada Tahun 2017 menjadi Rp. 72.001.000. Peningkatan disebabkan oleh meningkatnya aktivitas pelelangan ikan, yaitu di Pantai Popoh. Terjadinya peningkatan jumlah realisasi banyak mempengaruhi tingkat kontribusi realisasi Retribusi Tempat Pelelangan terhadap total penerimaan Retribusi Daerah Tahun 2017, tingkat kontribusi Tahun 2016 sebesar $0,04 \%$ dan meningkat menjadi $0,3 \%$.

Peningkatan realisasi tidak diimbangi oleh tingkat efektivitas pencapaian retribusi tempat pelelangan Tahun 2016 sebesar 13,24\% dengan kriteria tidak efektif. Sedangkan target penerimaan Tahun 2017 ditetapkan Rp. 71.500.000 telah berhasil terealisasi Rp. 72.001.000. Tingkat efektivitas sebesar $100,7 \%$ atau memiliki kriteria sangat efektif.

Tingkat efektivitas sebesar $0,003 \%$, artinya dalam pemungutan melalui dinas perikanan tidak efektif. Sedangkan pada Tahun 2017 dengan adanya realisasi yang mengalami pertumbuhan secara signifikan, maka tingkat efektivitas yang diperoleh dari proporsi antara realisasi retribusi tempat pelelangan terhadap PAD tumbuh $0,01 \%$, namun masih termasuk dalam kategori tidak efektif. Kondisi tersebut menunjukkan bahwa peran retribusi tempat pelelangan terhadap PAD masih kecil. Tingkat efisiensi menunjukan kriteria efisien dengan nilai sebesar tidak terhingga, dimana untuk memperoleh realisasi retribusi tempat pelelangan yang mencapai Rp. 72.001.000, maka biaya yang dikeluarkan untuk melakukan pemungutan sebesar Rp. 0,00.

\subsubsection{Retribusi Terminal}

Realisasi Tahun 2016 sebesar Rp. 194.689.000 dan mengalami pertumbuhan negatif/ penurunan sebesar 99,40\% pada Tahun 2017 menjadi Rp. 1.165.000,00. Penurunan disebabkan oleh adanya pengalihan pengelolaan terminal A dari Pemerintah Daerah kepada Kementerian Perhubungan, sehingga kewenangan pemerintah daerah untuk mengelola keberadaan terminal tersebut menjadi berkurang dan bahkan hilang. Hal ini juga berdampak pada tingkat kontribusi Tahun 2016 
sebesar $0,85 \%$ dan mengalami penurunan menjadi 0,005\% pada Tahun 2017.

Pada Tahun 2016 berhasil memenuhi target penerimaan Retribusi Terminal yang telah ditetapkan dengan target Rp. 180.000.000 dan menghasilkan realisasi Rp. 194.689.000. Tingkat efektivitas sebesar 108,16\% dengan kriteria sangat efektif. Pada Tahun 2017 seiring dengan perubahan kewenangan pengelolaan terminal A dari pemerintah daerah kepada Kementerian Perhubungan, maka selanjutnya tidak dilakukan penetapan target, namun masih menghasilkan retribusi sebesar Rp. 1.165.000.

Tingkat efektivitas yang diperoleh dari perbandingan antara realisasi terhadap PAD Tahun 2016 sebesar $0,06 \%$, dengan kategori tidak efektif dan mengalami penurunan menjadi $0,0002 \%$ atau dalam kriteria tidak efektif. Retribusi terminal memiliki nilai tingkat ekonomis sebesar 0\% (kriteria ekonomis). Dengan adanya pengalihan kewenangan selanjutnya Dinas Perhubungan tidak lagi menyediakan anggaran yang digunakan untuk melakukan pengelolaan/ pemungutan retribusi. Tingkat efisiensi menunjukan kriteria efisien dengan nilai sebesar tidak terhingga. Kondisi tersebut menggambarkan bahwa dengan tidak adanya biaya yang dianggarkan atau dikeluarkan masih mampu menghasilkan retribusi Rp. 1.165.000.

\subsubsection{Retribusi Tempat Khusus Parkir}

Realisasi Tahun 2016 Rp. 55.032.500 dan mengalami pertumbuhan sebesar $16,79 \%$ pada Tahun 2017 menjadi Rp. 64.270.500. Peningkatan disebabkan oleh bertambahnya jumlah kendaraan bermotor yang dimiliki oleh masyarakat, baik dalam bentuk Roda 2 (R2) maupun Roda 4 (R4). Dengan adanya peningkatan pendapatan pada Tahun 2017 menyebabkan tingkat kontribusi terhadap total penerimaan retribusi daerah mengalami pertumbuhan, dimana pada Tahun 2016 kontribusi mencapai 0,24\%, sedangkan pada Tahun 2017 mengalami peningkatan menjadi $0,27 \%$.

Target penerimaan telah tercapai dengan target sebesar Rp. 45.494.500 telah berhasil terealisasi Rp. 55.032.500 atau tingkat efektivitas 120,97\% dengan kriteria sangat efektif. Sedangkan target pada Tahun 2017 Rp. 53.443.950, telah terealisasi Rp. 64.270 .500 dengan tingkat efektivitas $120,26 \%$ atau dengan kriteria sangat efektif.

Tingkat efektivitas juga digambarkan dengan melihat pada hasil perbandingan antara realisasinya terhadap PAD dengan tingkat efektivitas sebesar 0,02\% dan $0,01 \%$ atau masuk kategori tidak efektif. Kondisi tersebut menunjukkan bahwa rendahnya peran yang diberikan oleh retribusi ini.

Tingkat ekonomis Tahun 2017 sebesar 100\% dengan kriteria ekonomis berimbang. Tingkat ekonomis menunjukkan perbandingan antara realisasi biaya dengan anggaran biaya yang ditetapkan, sehingga dengan demikian anggaran yang telah dirumuskan untuk mendukung pengelolaan/ pemungutan pada Tahun 2017 secara keseluruhan terealisasi.

Tingkat efisiensi pada Tahun 2017 menunjukan kriteria efisien dengan nilai sebesar $1,81 \%$. Tingkat efisiensi menunjukkan nilai yang dihitung berdasarkan persentase biaya pemungutan dengan realisasi penerimaan. Sehingga dengan demikian jumlah realisasi belanja/ biaya yang dikeluarkan untuk memperoleh pendapatan Tahun 2017 yang mencapai Rp. 7.439.954.500 adalah sebesar Rp. 134.562.500 atau sebesar $1,81 \%$.

\subsubsection{Retribusi Rumah Potong Hewan}

Realisasi retribusi ini pada Tahun 2016 sebesar Rp. 132.667.500 dan mengalami pertumbuhan sebesar 41,82\% pada Tahun 2017, menjadi sebesar Rp. 188.152.500. Terjadinya peningkatan realisasi disebabkan oleh bertambahnya jumlah permintaan potong hewan, mengingat tingkat konsumsi dan kebutuhan masyarakat akan daging semakin bertambah, sehingga jumlah ekor hewan yang dilakukan pemotongan juga mengalami peningkatan. Melihat pada tingkat kontribusi terhadap total penerimaan Retribusi Daerah pada Tahun 2016 dapat diketahui sebesar 0,58\%, sedangkan pada Tahun 2017 mengalami peningkatan menjadi sebesar $0,80 \%$.

Pada Tahun 2016 dan 2017 telah berhasil memenuhi target penerimaan, dimana pada Tahun 2016 dengan target penerimaan sebesar Rp. 132.000.000, telah realisasi sebesar Rp. 132.667.500. Dengan demikian tingkat efektivitas pencapaiannya Tahun 2016 memiliki kriteria sangat efektif dengan capaian sebesar 100,51\%. kemudian target penerimaan yang ditetapkan mengalami peningkatan menjadi Rp. 140.000.000 dengan realisasi penerimaan sebesar Rp. 188.152.500. Artinya telah berhasil mencapai target penerimaan dengan tingkat efektivitas sebesar $134,39 \%$ dengan kriteria sangat efektif.

Efektifitas terhadap PAD pada Tahun 2016 dan 2017 sebesar $0,04 \%$, atau dalam kategori tidak efektif. Sedangkan tingkat ekonomis sebesar 99,2\% dengan kriteria ekonomis, dimana dari keseluruhan biaya yang telah dianggarkan mampu terealisasi sebesar 99,2\%. Nilai tingkat efisiensi menunjukan kriteria tidak efisien dengan nilai $316,6 \%$. Terjadinya ketidak efisienan disebabkan oleh Fasilitasi Rumah Potong Hewan yang menelan biaya sangat besar, yaitu Rp. 497.300.000. Memang bila melihat pada biaya yang dikeluarkan pada Tahun 2017 termasuk besar, namun bila dilihat pada nilai manfaat yang diberikan dalam jangka panjang akan menghasilkan tingkat efisiensi yang wajar (efisien). Misalnya masa manfaat yang diberikan dengan adanya fasilitas Rumah Potong Hewan tersebut selama sepuluh 
tahun, maka penggunaan rata-rata biaya yang dikeluarkan dalam setiap tahunnya sebesar Rp. 49.730.000. Sehingga apabila biaya tersebut di tambahkan dengan peningkatan sarana dan prasarana yang diperkirakan mencapai Rp. 98.415.700 per tahun, maka dengan perkiraan tingkat pendapatan yang konstan selama sepuluh tahun (sebesar Rp. 188.152.500) masih memiliki tingkat efisiensi sebesar 78,74\% (efisien). Selain itu dengan masa manfaat yang dapat dinikmati dalam jangka panjang, maka secara tidak langsung dapat menekan biaya-biaya yang dikeluarkan pada tahun selanjutnya, misalnya pada Tahun 2018 hanya menganggarkan/ mengeluarkan biaya sebesar Rp. 100.000.000,00 untuk peningkatan sarana dan prasarana, maka dengan asumsi pendapatan yang tetap, yaitu sebesar Rp. 188.152.500,00 akan menghasilkan tingkat efisiensi sebesar $53,15 \%$, atau lebih efisien bila dibandingkan dengan Tahun 2017.

Tingkat efisiensi akan semakin meningkat (semakin efisien) apabila pendapatan retribusi yang diterima dalam setiap tahunnya mengalami peningkatan, artinya adanya pengeloaran yang besar mampu mendorong peningkatan jumlah pendapatan dimasa mendatang, sehingga untuk itu diperlukan pengelolaan secara cermat dengan menjaga dan meningkatkan tingkat efisiensi dimasa mendatang melalui peningkatan pendapatan dan mengendalikan biaya.

\subsubsection{Retribusi Tempat Rekreasi dan Olahraga}

Realisasi retribusi ini sebesar Rp. 16.550.000 Tahun 2016 dan mengalami pertumbuhan pada Tahun 2017 sebesar 347,46\% (Rp. 74.055.000). Peningkatan jumlah realisasi retribusi disebabkan oleh bertambahnya jumlah tempat rekreasi dan olahraga dan berdampak pada peningkatan kontribusi terhadap total penerimaan Retribusi Daerah yang mencapai 0,072\% Tahun 2016 dan mengalami peningkatan menjadi sebesar $0,31 \%$ pada Tahun 2017. Hal mengindikasikan peran yang diberikan dalam struktur Retribusi Daerah bertambah besar.

Target penerimaan Tahun 2016 sebesar Rp. 15.000.000 telah berhasil terealisasi sebesar Rp. 16.550.000. Tingkat efektivitas sebesar 110,33\%, masuk dalam kategori sangat efektif. Target penerimaan Tahun 2017 sebesar Rp. 46.580 .000 telah terealisasi Rp. 74.055.000 dengan tingkat efektivitas yang lebih tinggi, yaitu 158,98\% dengan kriteria sangat efektif.

Tingkat efektivitas yang dihitung dengan melihat perbandingan antara realisasi Retribusi Tempat Rekreasi dan Olahraga terhadap PAD menunjukkan adanya peningkatan. Pada Tahun 2016 tingkat efektivitas sebesar $0,005 \%$, artinya dalam pemungutannya masuk dalam kategori tidak efektif. Sedangkan pada Tahun 2017 tingkat efektivitas yang diperoleh dari perbandingan antara realisasi Retribusi terhadap PAD sebesar $0,01 \%$, namun walaupun mengalami pertumbuhan masih termasuk dalam kategori tidak efektif atau peran yang diberikan terhadap PAD masih kecil.

Nilai tingkat ekonomis sebesar 98,86\% dengan kriteria ekonomis, artinya dari keseluruhan jumlah biaya/ belanja yang telah dianggarkan Rp. 357.640.000, 98,86\% atau sebesar Rp. 353.557.400 telah terealisasi. Nilai tingkat efisiensi menunjukan kriteria tidak efisien dengan nilai sebesar $477,43 \%$. Terjadinya ketidakefisien antara lain disebabkan oleh tingginya biaya Peningkatan Proses Pelayanan Perijinan dan Pembangunan Gerbang GOR Lembu Peteng yang masing-masing mencapai Rp. 148.160.600 dan Rp. 195.454.000. Pengeluaran yang cukup besar diharapkan memberikan manfaat untuk peningkatan penerimaan retribusi di tahun-tahun mendatang. Bila melihat pada nilai manfaat yang diberikan dalam jangka menengah akan menghasilkan efisiensi dalam tingkat yang wajar (efisien). Misalnya masa manfaat yang diberikan selama enam tahun, maka penggunaan rata-rata biaya yang dikeluarkan dalam setiap tahunnya Rp. 57.269.100. Sehingga apabila biaya tersebut ditambahkan dengan biaya pemeliharaan yang diperkirakan mencapai Rp. 9.942.800 per tahun, maka dengan asumsi perkiraan tingkat pendapatan rata-rata selama enam tahun Rp. 74.055.000, maka memiliki tingkat efisiensi sebesar 90,76\% (efisien). Selain itu dengan masa manfaat yang dapat dinikmati dalam jangka menengah, maka secara tidak langsung dapat mengurangi biaya-biaya yang dikeluarkan pada tahun selanjutnya sehingga lebih efisien.

\subsubsection{Retribusi Penjualan Produksi Usaha Daerah}

Realisasi Rp. 127.875.000 pada Tahun 2016 dan mengalami pertumbuhan negatif/ penurunan sebesar $11,83 \%$ menjadi Rp. 112.750.000. Penurunan ini disebabkan oleh berkurangnya jumlah permintaan pasar terhadap hasil produksi usaha daerah. Hal ini berakibat pada menurunnya tingkat kontribusi dari $0,56 \%$ pada Tahun 2016 menjadi 0,48\% diTahun 2017.

Pada Tahun 2016 telah berhasil memenuhi target penerimaan Rp. 125.450 .000 dan realisasi penerimaannya Rp. 127.875.000. Tingkat efektivitas pencapaian Tahun 2016 adalah sebesar 101,93\% dan memiliki kriteria sangat efektif. Sebaliknya pada Tahun 2017 target penerimaan sebesar Rp. 117.950.000, namun hanya mampu terealisasi sebesar Rp. 112.750.000. Artinya belum berhasil mencapai target penerimaan dengan tingkat efektifitas sebesar 95,59\% atau cukup efektif.

Tingkat efektivitas yang diperoleh dari perbandingan antara realisasi terhadap PAD pada Tahun 2016 sebesar $0,04 \%$, artinya dalam pemungutannya masuk dalam kategori tidak efektif. Demikian pula dengan yang terjadi pada Tahun 2017, dimana tingkat efektivitas menurun menjadi sebesar $0,02 \%$, dan masih termasuk dalam kategori tidak efektif. Kondisi tersebut 
menunjukkan bahwa peran yang diberikan terhadap PAD masih sangat kecil.

Nilai tingkat ekonomis pada Tahun 2017 sebesar 99,79\% dengan kriteria ekonomis. Hal ini menunjukkan bahwa sebesar 99,79\% dari anggaran biaya yang dialokasikan untuk mengelola telah terserap, atau sebesar Rp. 99.790.000. Sedangkan tingkat efisiensi memberikan gambaran mengenai nilai yang dihitung berdasarkan persentase biaya pemungutan retribusi daerah dengan realisasi penerimaan retribusi daerah. Nilai tingkat efisiensi pada Tahun 2017 menunjukkan kriteria efisien dengan nilai sebesar $88,5 \%$. Artinya untuk memperoleh pendapatan retribusi sebesar Rp. 112.750.000, maka jumlah biaya yang dikeluarkan pada Tahun 2017 mencapai Rp. 99.790.000.

\subsubsection{Retribusi Ijin Mendirikan Bangunan (IMB)}

Retribusi IMB dikelola oleh Dinas Penanaman Modal dan PTSP. Jumlah realisasi Retribusi IMB sebesar Rp. 694.333.091 pada Tahun 2016; dan tumbuh sebesar 9,19\% menjadi Rp. 758.173.317 pada Tahun 2017. Terjadinya peningkatan disebabkan adanya peningkatan pengajuan IMB akibat meningkatnya perumahan baru. Tingkat kontribusi terhadap total penerimaan Retribusi Daerah juga meningkat seiring dengan meningkatnya jumlah realisasi, yaitu sebesar $3,06 \%$ dan meningkat menjadi 3,25\% pada Tahun 2017.

Target penerimaan IMB tercapai, dimana target Tahun 2016 sebesar Rp. 661.000.000, telah terealisasi Rp. 694.333.091 atau tingkat efektivitasnya 105,043\% (memiliki kriteria sangat efektif). Sedangkan Tahun 2017 target penerimaan Rp. 717.185.000 telah terealisasi Rp. 758.173.317 atau tingkat efektivitas sebesar 105,72\% (memiliki kriteria sangat efektif).

Tingkat efektivitas (perbandingan antara realisasi Retribusi IMB terhadap PAD) Tahun 2016 sebesar 0,15\% masuk dalam kategori kurang efektif. Seiring dengan meningkatnya jumlah realisasi, tingkat efektivitas pada Tahun 2017 meningkat menjadi 0,2\%, namun masih dalam kategori kurang efektif. Sehingga peran dari Retribusi IMB dalam struktur PAD tergolong kecil.

Nilai tingkat ekonomis Retribusi IMB Tahun 2017 sebesar 99\% dengan kriteria ekonomis, artinya tingkat penyerapan anggaran untuk membiayai kegiatan yang berkaitan dengan pengelolaan/ pemungutan retribusi IMB masih berada di bawah anggaran yang ditetapkan. Sedangkan nilai tingkat efisiensi Retribusi IMB Tahun 2017 menunjukan kriteria efisien dengan nilai sebesar $43,7 \%$, dimana jumlah biaya yang dikeluarkan untuk mendapatkan pendapatan retribusi Rp. 758.173.317 adalah sebesar Rp. 331.966 .400 atau 43,7\%.

\subsubsection{Retribusi Izin Gangguan}

Realisasi pada Tahun 2016 sebesar Rp. 563.181.070 dan mengalami pertumbuhan negatif / penurunan sebesar
-53,96\% Tahun 2017 menjadi Rp. 259.311.650. Penurunan diakibatkan oleh perpanjangan izin gangguan yang sudah tidak dikenakan retribusi. Tingkat kontribusi realisasi Retribusi Izin Gangguan terhadap total penerimaan Retribusi Daerah pada Tahun 2016 sebesar $2,48 \%$, seiring dengan adanya penurunan realisasi pada Tahun 2017 menyebabkan nilai kontribusi mengalami penurunan menjadi $1,11 \%$.

Target penerimaan Rp. 560.000 .000 berhasil tercapai dengan realisasi Rp. 563.181.070 atau tingkat efektivitasnya sebesar $100,57 \%$ dengan kriteria sangat efektif. Sedangkan pada Tahun 2017, target Rp. 250.000.000 dengan realisasi penerimaan sebesar Rp. 259.311.650 dengan tingkat efektivitas sebesar 103,72\% atau dengan kriteria sangat efektif.

Tingkat efektivitas terhadap PAD pada Tahun 2016 sebesar $0,16 \%$, artinya dalam pemungutan termasuk dalam kategori kurang efektif. Demikian pula pada Tahun 2017, dimana tingkat efektivitas mengalami penurunan menjadi 0,05\%, masuk kategori tidak efektif. Dapat disimpulkan peran retribusi izin gangguan terhadap PAD masih sangat kecil.

Nilai tingkat ekonomis Tahun 2017 sebesar 98,7\% dengan kriteria ekonomis, artinya penyerapan anggaran untuk membiayai pengelolaan pada Tahun 2017 sebesar 98,7\% atau Rp. 197.499.300. Sedangkan nilai tingkat efisiensi Tahun 2017 menunjukan kriteria efisien dengan nilai sebesar 76,1\%. Kondisi tersebut menggambarkan bahwa biaya yang dikeluarkan untuk memperoleh pendapatan retribusi Rp. 259.311.650 adalah Rp. 197.499.300 atau 76,1\% dari jumlah pendapatan.

\subsubsection{Retribusi Izin Trayek}

Realisasi Tahun 2016 sebesar Rp. 5.935 .000 dan mengalami pertumbuhan negatif/ penurunan sebesar 6,48\% pada Tahun 2017 menjadi sebesar Rp. 5.550.000. Penurunan disebabkan oleh adanya Mobil Penumpang Umum (MPU) yang tidak beroperasi dan memiliki alih fungsi. Tingkat kontribusinya terhadap total penerimaan retribusi daerah pada Tahun 2016 sebesar 0,03\%, seiring dengan adanya penurunan jumlah realisasi menyebabkan pada Tahun 2017 mengalami penurunan menjadi 0,02\%.

Pada Tahun 2016 dan 2017 target penerimaan tercapai, dimana pada Tahun 2016 dengan target Rp. 5.500.000 berhasil terealisasi sebesar Rp. 5.935.000. Dengan demikian tingkat efektivitas pencapaian Tahun 2016 sebesar $107,91 \%$ dengan kriteria sangat efektif. Sedangkan target pada Tahun 2017 adalah sebesar Rp. 5.500.000; dengan realisasi penerimaan Rp. 5.550.000 atau tingkat efektivitasnya $100,91 \%$ atau dengan kriteria sangat efektif.

Pada Tahun 2016 tingkat efektivitas (proporsi terhadap total PAD) sebesar $0,002 \%$, artinya pemungutan termasuk dalam kategori tidak efektif dan mengalami penurunan menjadi $0,001 \%$, atau kategori tidak efektif. 
Kecilnya nilai efektivitas menunjukkan bahwa peran yang diberikan terhadap PAD sangat kecil.

Tingkat ekonomis menunjukkan bahwa nilai tingkat ekonomis Tahun 2017 sebesar 0\% dengan kriteria ekonomis, artinya pada Tahun 2017 Dinas Perhubungan tidak menganggarkan belanja yang digunakan untuk mengelola/ melakukan pemungutan. Nilai tingkat efisiensi pada Tahun 2017 menunjukan kriteria efisien dengan nilai tidak terhingga, dimana dengan tanpa adanya belanja yang digunakan untuk mengelola/ melakukan pemungutan telah berhasil terealisasi Rp. 5.550.000.

\subsection{Analisis Overlay Retribusi Daerah}

Berdasarkan analisis overlay, diketahui bahwa terdapat empat jenis retribusi dengan kategori prima, artinya retribusi daerah memberikan kontribusi dan pertumbuhan sama dengan atau lebih dari $1 \%$, yaitu seperti retribusi pelayanan kesehatan, retribusi pelayanan parkir di tepi jalan umum, retribusi pelayanan pasar, dan IMB. Lebih lanjut, terdapat empat jenis dengan kategori potensial, yaitu: retribusi pelayanan persampahan, retribusi pengujian kendaraan bermotor, retribusi pemakaian kekayaan daerah, dan retribusi izin gangguan; dimana retribusi daerah tersebut memberikan kontribusi sama dengan atau lebih dari $1 \%$ sedangkan pertumbuhannya kurang dari $1 \%$. Pada retribusi pasar grosir dan/ atau pertokoan, retribusi tempat pelelangan, retribusi tempat khusus parkir, retribusi rumah potong hewan, dan retribusi tempat rekreasi dan olahraga; termasuk dalam katagori berkembang dimana retribusi daerah memberikan kontribusi kurang dari $1 \%$ sedangkan pertumbuhan sama dengan atau lebih dari $1 \%$. Sedangkan untuk katagori terbelakang hanya tiga jenis retribusi yaitu, retribusi terminal, retribusi penjualan produksi usaha daerah, dan retribusi izin trayek; karena kontribusi dan pertumbuhan kurang dari $1 \%$.

\section{Daftar Pustaka}

Agus, Prawoto. (2011). Pengantar Keuangan Publik. Yogyakarta: BPFE.

Basso, Anang. (2017). Tarif Parkir GOR Lembu Peteng Mencekik, Dishub Panik. Tulungagung Times.com [Internet], 17 Mei 2017. Dapat diakses pada https://www.tulungagungtimes.com/baca/153445/ 20170517/164606/tarif-parkir-gor-lembu-petengmencekik-dishub-panik/ [Diakses pada 1 Mei 2019].

Jaya, W.K. (1996). Analisis Keuangan Daerah; Pendekatan Makro, Model Program PMSES. Kerjasama Ditjrn PUOD Depdagri dengan Pusat Penelitian dan Pengkajian Ekonomi dan Bisnis, UGM, Yogyakarta.
Mahmudi. (2010). Manajemen Kinerja Sektor Publik. Yogyakarta: UPP STIM YKPN.

Mahsun, Mohamad. (2013). Pengukuran Kinerja Sektor Publik. Yogyakarta: BPFE.

Pramono, Joko. (2017). Ketua DPRD Tulungagung akui Perda Minuman Beralkohol Mandul. Jatim Times.com [Internet], 16 Agustus 2017. Dapat diakses pada https://m.jatimtimes.com/baca/157043/20170816/ 200540/ketua-dprd-tulungagung-akui-perdaminuman-beralkohol-mandul/ [Diakses pada 1 Mei 2019].

Siahaan, Marihot P. (2005). Pajak Daerah dan Retribusi Daerah. Jakarta: PT Raja Grafindo Persada.

Yani, Ahmad. (2002). Hubungan Keuangan Antara Pemerintah Pusat dan Daerah di Indonesia. Jakarta: Raja Grafindo Persada. 